\title{
Class Management As A Determinative Factor Toward Learning Result (A Study to Economic Subject Student High and Low Group in Public Senior High Schools in Singkawang)
}

\author{
Junaidi H. Matsum \\ Tanjungpura University, Pontianak, Indonesia \\ E-mail: prof.junaidimatsum@yahoo.com
}

\begin{abstract}
A special objective research: 1. Class management of XI IPS1 high group students and low group students among all Public Senior High Schools in Singkawang. 2. Study results of economic subjects from students XI IPS1 with high and low group in Public Senior High Schools in Singkawang. 3. Class management is a determinative factor of students' learning result of high and low group in Public Senior High Schools in Singkawang. Urgency of the research: Practically for students: 1. Class management as an effort to improve student motivation in the learning process of economic subjects study. 2 .Improving students' study result in economic subject .For teachers: 1 . This research can give significant contribution for economic teachers in order to manage the class better. 2. Improving the quality of teaching and learning. For school: 1 . Give contributions in improving quality of teachers. 2. Improving the rank of school success. Theoritically: The result of this research is expected to be able to increase teachers' knowledge in general that is related to the theories about class management and study result.
\end{abstract}

Keywords: Class Management, Study Result, Public Senior High School

\section{INTRODUCTION}

Guru sebagai tenaga professional di bidang keguruan penting untuk mengetahui persoalan-persoalan yang bersifat filosofis dan konseptual, serta melaksanakan hal-hal yang bersifat teknis dalam pembelajaran. Hal-hal yang bersifat teknis ini di antaranya adalah keterampilan mengelola kelas. Sardiman A.M. (2014:169) mengemukakan: "Untuk mengajar suatu kelas, guru dituntut mampu mengelola kelas, yakni menyediakan kondisi yang kondusif untuk berlangsungnya proses belajar mengajar. Kalau belum kondusif, guru harus berusaha untuk membenahinya”. Menurut Sudirman N. dkk. (1991:310) "Penggelolaan kelas adalah upaya mendayagunakan potensi kelas". Oleh karena itu, kegiatan pengeloaan kelas akan menyangkut: "mengatur tata ruang kelas yang memadai untuk pengajaran dan menciptakan iklim belajar mengajar yang serasi" Sardiman A.M., 2014:169). Selanjutnya Mudasir (2011:83) mengemukakan: "Salah satu faktor penting dalam belajar adalah lingkungan".

Pengelolaan kelas dalam proses belajar pembelajaran merupakan faktor yang penting. Kelas akan kondusif untuk kegiatan proses belajar mengajar apabila dikelola oleh guru dengan baik. Keterampilan dalam pengeloaan kelas merupakan satu di antara indikator keterampilan melaksanakan pembelajaran dengan baik. Hal ini disebabkan bahwa pengelolaan kelas merupakan suatu kegiatan dalam proses belajar pembelajaran yang berkaitan dengan: (1) pengaturan tata ruang kelas, yang diharapkan memadai untuk pembelajaran; dan (2) pengelolaan siswa, dalam rangka menciptakan iklim belajar pembelajaran yang serasi. Berdasarkan pendapat di atas, kegiatan pengelolaan kelass tersebut menyangkut mengatur kondisi fisik lingkungan kelas sampai dengan menciptakan suasana belajar pembelajaran yang kondusif oleh seorang guru dengan mendayagunakan seluruh potensi yang berada di lingkungan sekolah demi mencapai tujuan guruannya. Kegiatan pengelolaan kelas sangat urgen dalam rangka memudahkan guru dan siswa untuk mencapai tujuan pembelajaran. Di lain pihak kegaduhan dan suasana yang tidak kondusif akan menghambat dan memperlambat pencapaian tujuan pembelajaran.

Pengelolaan kelas menurut Lois (dalam Made Pidarta, tanpa tahun:102) diartikan sebagai "proses mengorganisasi dan mengkoordinasi kemauan murid-murid untuk menyelesaikan tujuan guruannya. Proses ini membutuhkan seleksi dan penggunaan alat-alat yang cocok dengan problem pengelolaan dan situasi kelas yang terjadi pada waktu tertentu". Pengelolaan kelas yang baik ditujukan untuk mengatur sarana pembelajaran agar semua siswa yang berada di dalam kelas dapat belajar secara maksimal dan apabila terjadi gangguan di dalam kelas guru berupaya mengendalikan suasana belajar yang menyenangkan untuk mencapai tujuan pembelajaran.

Pada dasarnya, dalam konsep pengelolaan kelas ada dua kegiatan yang dilakukan guru. Pertama bersifat preventif, dalam hal ini guru berupaya menata segala sarana untuk kegiatan belajar pembelajaran dan mengarahkan siswa untuk 
mengikuti pembelajarran dengan baik. Kedua, bersifat kuratif, dalam hal ini guru berupaya untuk memperbaiki kondisi kelas apabila terjadi gangguan pada waktu pelaksanaan proses belajar pembelajaran. Disinilah perlunya perhatian, pengarahan, bimbingan, dan kepedulian guru untuk memperhatikan perilaku siswanya pada saat proses belajar pembelajaran.

Hadari Nawawi (1989:115) mengemukakan:

Kegiatan manajemen atau pengelolaan kelas dapat diartikan sebagai kemampuan guru atau wali kelas dalam mendayagunakan potensi kelas berupa pemberian kesempatan yang seluas-luasnya pada setiap personal untuk melakukan kegiataan-kegiatan yang kreatif dan terarah sehingga waktu dan dana yang tersedia dapat dimanfaatkan secara efisien untuk melakukan kegiatan-kegiataan kelas yang berkaitan dengan kurikulumdan perkembangan murid.

Tujuan Pengelolaan kelas menurut Santrock, John W. (2011:558) adalah: "Membantu murid menghabiskan lebih banyak waktu untuk belajar dan mengurangi waktu aktivitas yang tidak diorientasikan pada tujuan, dan mencegah murid mengalami problem akademik dan emosional". Kemudian Hamid Darmadi (2012:6) mengemukakan: "Tujuan guru mengelola kelas adalah agar semua siswa yang ada di dalam kelas dapat belajar dengan optimal dan mengatur sarana pembelajaran serta mengendalikan suasana belajar yang menyenangkan untuk mencapai tujuan belajar".

Secara khusus beberapa persoalah pengelolaan kelas menurut Syaiful Bahri Djamarah dan Aswan Zain (2013:195) dapat diidentifikasi sebagai berikut:

1. Cenderung tidak ada standar perilaku dalam bekerja kelompok, misalnya rebut, bercakap-cakap, pergi ke sana kemari dan lain-lain.

2. Kelas ment oleransi kekeliruan-kekeliruan temannya ialah menerima dan mendorong perilaku siswa yang keliru.

3. Tidak mampu menyesuaikan dengan lingkungan yang berubah, seperti tugas-tugas tmbahan, anggota kelas yang baru, situasi yang baru, dan sebagainya.

4. Reaksi negative terhadap anggota kelompok, misalnya rebut bermusuhan, mengucilkan, merendahkan kelompok bodoh, dan sebagainya.

5. Mudah mereaksi ne3gatif,terganggu, misalnya bila didatangi monitor, tamu-tamu, iklim yang berubah, dan sebagainya.

Selanjutnya, hasil belajar merupakan suatu tingkat keberhasilan yang dicapai oleh siswa diperoleh dari proses belajar pembelajaran. Menurut Syaiful Bahri Djamarah dan Aswan Zain (2013:177) menyimpulkan pengelolaan kelas yaitu: "Merupakan kegiatan pengaturan kelas untuk kepentingan pengajaran". Di lain pihak masih ditemui adanya sikap dari pihak guru yang kurang antusias dalam melakukan pengelolaan kelas yang relatif baik. Dengan demikian, pengelolaan kelas bukanlah persoalan yang mudah. Guru yang cenderung belum berpengalaman merasakan betapa sukarnya mengelola kelas. Keberhasilan dan kegagalan seorang guru mencapai tujuan pembelajaran sejalan dengan ketidakmampuannya dalam mengelola kelas. Indikator dari kegagalan itu adalah hasil belajar siswa rendah, atau masih ada yang belum tuntas khususnya pada mata pelajaran ekonomi. Karena itu pengelolaan kelas merupakan suatu keterampilan mengajar yang sangat penting dikuasai oleh guru dalam rangka meningkatkan hasil belajar siswa.

Hasil belajar pada dasarnya merupakan tingkat penguasaan yang diperoleh dalam mengikuti program belajar mengajar dengan tujuan yang telah ditentukan. Menurut Muhibbin Syah (2012:68) belajar adalah: "Tahapan perubahan seluruh tingkah laku individu yang relatif menetap sebagai hasil pengalaman dan interaksi dengan lingkungannya yang melibatkan proses kognitif'. Dengan demikian, disimpulkan bahwa belajar merupakan serangkaian kegiatan yang dilakukan terus-menerus untuk memperoleh suatu perubahan tingkah laku sebagai hasil dari pengalaman seseorang dalam interaksi dengan lingkungannya yang menyangkut kognitif, afektif, dan psikomotor.

Mengingat begitu pentingnya pengelolaan kelas sebagai suatu keterampilan yang harus dimiliki guru maka persoalan ini menjadi perhatian penulis. Berdasarkan harapan dan kenyataan di atas, maka penulis merasa tertarik untuk meneliti: Pengelolaan Kelas Sebagai Faktor Determinatif Hasil Belajar (Studi Pada Mata Pembelajaran Ekonomi Siswa SMA Negeri Se-Kota Singkawang).

\section{METODE PENELITIAN}

\section{A. Jenis Penelitian}

Metode penelitian yang digunakan adalah metode deskriptif sebagai metode yang sesuai dengan penelitian ini, karena metode ini menjelaskan data yang ada pada saat penelitian dilakukan. Hal ini sejalan dengan pendapat Hadari Nawawi (2012:67) sebagai berikut: "Metode deskriptif dapat diartikan sebagai prosedur pemecahan masalah yang diselidiki dengan menggambarkan/melukiskan keadaan subyek/obyek penelitian (seseorang, lembaga, masyarakatdan lain-lain) pada saat sekarang berdasarkan fakta-fakta yang tampak, atau sebagaimana adanya. Dari pengertian tersebut, maka peneliti menyimpulkan bahwa metode deskriptif adalah suatu cara pemecahan masalah dengan memperlihatkan keadaan atau peristiwa tentang suatu obyek penelitian yang berlangsung pada saat penelitian dilakukan sebagaimana adanya.

Bentuk penelitian yang digunakan yakni bentuk studi hubungan (interrelationship studies). Bentuk penelitian studi hubungan dalam penelitian ini tidak hanya bertujuan untuk memaparkan hubungan obyek penelitian, tetapi juga memaparkan pengelolaan kelas sebagai faktor determinatif terhadap hasil belajar mata pelajaran ekonomi siswa kelas XI IPS1 kelompok tinggi dan kelompok rendah SMA Negeri Se-Kota Singkawang. 


\section{B. Populasi dan Sampel}

Populasi dalam penelitian ini adalah siswa yang memiliki karakteristik sebagai berikut: (1) siswa kelas XI IPS1; (2) siswa yang mengikuti mata pelajaran Ekonomi; (3) Siswa yang memiliki nilai mata pelajaran ekonomi kelompok tinggi dan kelompok rendah pada semester genap tahun ajaran 2014/2015 SMA Negeri Se-Kota Singkawang.

Menginggat jumlah populasi dalam penelitian ini relatif besar, maka diperlukkan sampel penelitian. Penentuan sampel dalam penelitian ini melalui teknik probability sampling. Setelah teknik ini, dilanjutkan melakukan random sampling. Berdasarkan hasil random sampling diperoleh sampel sebanyak 101 orang responden siswa kelas X1 IPS1 SMA Negeri Se-Kota Singkawang, dengan rincian sebagai berikut: SMA Negeri 1 Singkawang 10 orang, SMA Negeri 2 Singkawang 10 orang, SMA Negeri 3 Singkawang 10 orang, SMA Negeri 4 Singkawang 10 orang, SMA Negeri 5 Singkawang 10 orang, SMA Negeri 6 Singkawang 10 orang, SMA Negeri 7 Singkawang 10 orang, SMA Negeri 8 Singkawang 10 orang, SMA Negeri 9 Singkawang 10 orang, SMA Negeri 10 Singkawang 11 orang.

\section{Teknik Pengumpulan Data}

Teknik pengumpulan data yang dipergunakan adalah: 1 . Teknik Komunikasi Langsung dengan alat Pedoman Wawancara, 2. Teknik komunikasi tidak langsung dengan alatnya berpua angket, dan 3. Teknik studi dokumenter dengan alat pengumpul data berupa lembar catatan.

\section{Teknik Analisis Data}

Teknik analisis data dilakukan setelah ada pengujian validitas ddan reliabelitas instrumen penelitian (khususnya angket). Analisis data meliputi perhitungan persentase dari setiap item angket, uji prasyrat analisis regresi, analisis regresi, analisis korelasi, dan melakukan perhitungan koefisien determinasi. Penghitungan dalam hal ini menggunakan program komputer Statistical Product and Service Solution (SPSS)22.

\section{HASIL DAN PEMBAHASAN}

Berdasarkan hasil uji coba validitas angket yang disebarkan kepada 15 siswa kelas X1 IPS2 SMA Negeri 5 Kota Singkawang bahwa dari 22 butir pertanyaan angket terdapat 18 butir dinyatakan valid dan empat butir dinyatakan tidak valid. Dengan demikian, untuk pengambilan data penelitian maka angket yang akan disampaikan kepada responden penelitian hanya sebanyak 18 butir pertanyaan. Uji reliabelitas dilakukan dengan menggunakan bantuan program Statistical Product and Service Solusion (SPSS) versi 22 dengan teknik Alpha Cronbach. Nilai Cronbach's Alpha sebesar 0,951adalah termasuk kategori baik karena berada di atas 0,6. Dengan demikian, dapat dinyatakan bahwa angket tersebut reliabel. Oleh karena itu, angket tersebut dapat digunakan untuk pengambilan data dalam penelitian.
Data dari setiap butir angket tentang pengelolaan kelas oleh guru pada mata pelajaran ekonomi kelas XI IPS1 SMA Negeri Se-Kota Singkawang (variabel $X$ ) diolah dan dianalisis deskriptif persentase. Pengelolaan kelas XI IPS1 Siswa Kelompok Tinggi dan Kelompok Rendah SMA Negeri Se-Kota Singkawang sudah berjalan dengan baik. Kondisi ini dapat dilihat dari rata-rata persentase indikator yaitu $77,08 \%$.

Selanjutnya, data tentang hasil belajar merupakan data hasil ulangan harian mata pelajaran ekonomi siswa kelas XI IPS1 SMA Se-Kota Singkawang yang dilakukan pengelolaan kelas oleh guru pada saat penelitian. Berdasarkan data hasil penelitian setelah dikategorikan maka terdapat 30 siswa (30\%) yang mempunyai nilai sangat tinggi karena berada pada rentang nilai $80-100$, dan 55 siswa (54\%) mempunyai nilai yang tinggi karena berada pada rentang nilai $70-79$, serta 16 siswa (16\%) yang mempunyai nilai cukup karena berada pada rentang nilai 60-69. Selain itu tingkat ketuntasan dari 101 siswa terdapat $85(84,16 \%)$ siswa yang tuntas. Sedangkan sisanya masih terdapat 16 siswa $(15,84 \%)$ siswa yang belum tuntas. Secara umum hasil belajar mata pelajaran ekonomi Siswa kelas XI IPS1 Kelompok Tinggi dan Kelompok Rendah SMA Negeri SeKota Singkawang sebagai hasil pengelolaan kelas oleh guru pelajaran ekonomi termasuk kategori tinggi dengan nilai rata-rata 77,33 .

\section{A. Pengelolaan kelas XI IPS1 Siswa Kelompok Tinggi dan Kelompok Rendah SMA Negeri Se-Kota Singkawang sudah berjalan dengan baik.}

Secara umum seluruh indikator persentase yang mewakili variabel pengelolaan kelas dalam pembelajaran ekonomi kelas XI IPS 1 SMA Negeri Se Kota Singkawang di rataratakan, dengan nilai persentase $77,08 \%$. Dapat disimpulkan bahwa pengelolaan kelas oleh guru-guru pelajaran ekonomi kelas XI IPS 1 SMA Negeri Se Kota Singkawang tersebut berada dalam kategori baik karena berada pada rentang persentase $61 \%-80 \%$.

Data tersebut didukung oleh hasil wawancara peneliti bahwa pengelolaan kelas yang dilakukan guru-guru di antaranya merupakan penyediaan fasilitas bagi berbagai kegiatan belajar siswa dan lingkungan sosial, emosional, dan intelektual dalam kelas. Kondisi tersebut sejalan dengan pendapat Sardiman (2012:169): "kegiatan mengelola kelas menyangkut mengatur tata ruang kelas yang memadai untuk pengajaran dan menciptakan iklim belajar mengajar yang serasi”.

Abdurahman (2011:201) mengemukakan "pengelolaan kelas sebagai semua upaya dan tindakan guru dalam membina dan memodalisasi serta menggunakan sumber daya kelas secara optimal, selektif dan efisien untuk menciptakan kondisi atau menyelesaikan problema kelas agar proses pembelajar dapat berlangsung wajar". Lebih luas lagi pengertian pengeloaan kelas sebagaimana dikemukakan Wina Sanjaya (2008:44) sebagai berikut: "Pengelolaan kelas adalah keterampilan guru menciptakan dan memelihara 
kondisi belajar yang optimal dan mengembalikannya manakala terjadi hal-hal yang dapat menganggu suasana pembelajaran. Lebih lanjut dikemukakan oleh J.J. Hasibuan dan Moedjiono (1995:82): "mengelola kelas adalah keterampilan guru untuk menciptakan dan memelihara kondisi belajar yang optimal dan mengembalikannya kekondisi yang optimal jika terjadi gangguan, baik dengan cara mendisiplinkan ataupun melakukan kegiatan remedial". Keterampilan mengelola kelas seperti pengaturan kondisi fisik kelas hingga penciptaan suasana belajar yang kondusif oleh guru dengan mendayagunakan seluruh potensi siswa yang berada di lingkungan sekolah yang demikian tentu ditujukan guna mencapai tujuan pendidikannya. Di samping itu hasil wawancara menunjukkan bahwa pengelolaan siswa dalam kelas yang dilakukan guru mata pelajaran ekonomi kelas XI IPS 1 sudah sudah berjalan baik. Optimalisasi tersebut dilihat dari adanya pengelompokkan siswa dan penanganan konflik dalam kelas. Menunjukkan bahwasannya guru telah melaksanakan pengelolaan siswa denga baik. Hasil tersebut juga didukung berdasarkan observasi dan wawancara peneliti di lapangan. Di antara pengelolaan siswa yang dilakukan oleh guru yakni mengelompokkan siswa dalam kelompok belajar pada saat materi atau pada saat member tugas-tugas dalam mata pelajaran ekonomi. Pengelompokkan kadang ditentukan oleh guru dan kadang juga ditentukan oleh siswa sehingga dalam pengelompokkan tersebut siswa merasa sesuai dengan kebutuhannya. Di samping itu, guru juga memberikan motivasi pada siswa agar berperan aktif dalam kelompok pembelajaran. Guru juga melaksanakan penanganan konflik siswa dalam kelas. Berdasarkan data dilapangan konflik yang terjadi dalam kelas pada saat mata pelajaran ekonomi berlangsung, berupa olok-olokan, ngobrol pada saat guru menjelaskan, ribut, keluar masuk kelas akan tetapi belum pernah terjadi konflik yang sungguhan. Dan tindakan yang guru lakukan adalah menegur dan pengarahan. Guru juga selalu memberikan penghargaan terhadap siswa berupa pujian apabila siswa melakukan hal positif.

Berdasarkan data hasil wawancara diketahui bahwa pengelolaan lingkungan fisik yang juga menentukan keberhasilan pengelolaan kelas dalam penelitian ini juga sudah berjalan baik. Pada aspek pengelolaan lingkungan fisik kelas ada beberapa indikator yang mendukung keberhasilnannya yaitu pengaturan tempat duduk, pengaturan alat-alat pengajaran, penataan keindahan kelas, dan ventilasi termasuk pencahayaan berjalan baik. Kondisi di atas menunjukkan bahwa lingkungan fisik kelas yang baik dapat berpengaruh terhadap sebagai aspek yang harus diperhatikan pada pengelolaan kelas. Hasil tersebut juga diperkuat dengan hasil wawancara terhadap guru mata pelajaran ekonomi kelas XI IPS 1 bahwa menurut guru lingkungan fisik kelas yang baik sangat mempengaruhi proses belajar dan pembelajaran. Menurut guru mata pelajaran ekonomi, kelas harus bersih dari sampah-sampah disekitar kelas, tempat duduk tertata rapi tidak berantakan, tas-tas dan helm siswa diletakkan pada tempatnya. Sebelum melaksanakan proses belajar pembelajaran di kelas, guru mata pelajaran ekonomi memastikan bahwa siswa sudah siap belajar, baik itu kelas dari segi tatanan keindahannya, variasi kursi siswa (biasanya menggunakan bentuk klasikal), media pembelajaran (buku cetak dan Infokus) dan siswanya. Berdasarkan angket penelitian, hasil untuk indikator ke empat yatu ventilasi dan pencahayaan mendapatkan nilai tertinggi yakni 77\%. Hal ini juga sesuai dengan hasil wawancara yang dilakukan pada guru mata pelajaran yang menyatakan bahwa kelas yang cukup sirkulasi udara dan ketersediaan pendingin ruangan dan pencahayaan kelas menjadi faktor yang membuat siswa nyaman berada di kelas yang merupakan hal penting dalam pengelolaan kelas.

\section{B. Hasil Belajar Mata Pelajaran Ekonomi Siswa Kelas XI} IPS 1 Kelompok Tinggi dan Kelompok Rendah SMA

Negeri Se-Kota Singkawang Termasuk Kategori Tinggi.

Berdasarkan data hasil penelitian setelah dikategorikan maka terdapat 30 siswa (30\%) yang mempunyai nilai sangat tinggi karena berada pada rentang nilai 80-100, dan 55 (54\%) siswa mempunyai nilai yang tinggi karena berada pada rentang nilai 70-79, serta 16 siswa (16\%) yang mempunyai nilai cukup karena berada pada rentang nilai 60 69. Selain itu tingkat ketuntasan dari 101 siswa terdapat 85 $(84,16 \%)$ siswa yang tuntas. Sedangkan sisanya masih terdapat 16 siswa $(15,84 \%)$ siswa yang belum tuntas.

Secara umum hasil belajar mata pelajaran ekonomi Siswa kelas XI IPS1 Kelompok Tinggi dan Kelompok Rendah SMA Negeri Se-Kota Singkawang sebagai hasil pengelolaan kelas oleh guru pelajaran ekonomi termasuk kategori tinggi dengan nilai rata-rata 77,33. Tingginya hasil belajar tersebut ditentukan oleh pengelolaan kelas oleh guru mata pelajaran ekonmomi. Menurut Sudirman N dalam Isrotul (2013:11) secara umum tujuan pengelolaan kelas adalah:

Penyediaan fasilitas bagi bermacam-macam kegiatan belajar siswa dan lingkungan sosial, emosional dan intelektual dalam kelas. Fasilitas itu memungkinkan siswa belajar dan bekerja, terciptanya lingkungan sosial yang memberikan kepuasan, suasana disiplin, perkembangan intelektual, emosional dan sikap serta apresiasi pada siswa.

Sedangkan menurut John W. Santrock (2011:558) menyatakan tujuan pengelolaan kelas menjadi dua yaitu: "Membantu murid menghabiskan lebih banyak waktu untuk belajar dan mengurangi waktu aktivitas yang tidak diorientasikan pada tujuan, dan mencegah murid mengalami problem akademik dan emosional". Guru sangat berperan penting dalam pengelolaan kelas. Apabila guru mampu mengelola kelasnya dengan baik maka tidaklah sukar bagi guru itu untuk mencapai tujuan pembelajaran yang telah dirumuskan. Tercapainya tujuan pembelajaran pada akhirnya dapat meningkatkan hasil belajar siswa.

C. Pengelolaan Kelas Merupakan Faktor Determinatif Terhadap Hasil Belajar Siswa Kelas X1 IPS 1 Kelompok 


\section{Tinggi Dan Kelompok Rendah SMA Negeri Se-Kota} Singkawang

Berdasarkan nilai persamaan regresinya adalah $\mathrm{Y}=$ $52,657+0,466 X$. Artinya nilai konstanta adalah 52,657 yaitu jika pengelolaan kelas (X) bernilai 0 (nol), maka hasil belajar (Y) bernilai 52,657. Selanjutnya, nilai koefisien regresi variabel pengelolaaan kelas $(\mathrm{X})$ yaitu 0,466 ini berarti bahwa setiap peningkatan pengelolaan kelas sebesar satu, maka hasil belajar akan meningkat sebesar 0.466 . Tingkat keeratan hubungan pengelolaan kelas dengan hasil belajar ditunjukkan dengan besarnya koefisien korelasi $(\mathrm{R})$ sebesar 0,501 termasuk kategori sedang.

Penentuan pengaruh semua aspek variabel pengelolaan kelas terhadap nilai variabel hasil belajar ditunjukkan oleh besarnya koefisen determinasi $\left(\mathrm{R}^{2}\right)$ sebesar 0,251 artinya persentase sumbangan pengaruh pengelolaan kelas terhadap hasil belajar sebesar $25,1 \%$ sedangkan sisanya sebesar $74,9 \%$ dipengaruhi oleh variabel lain yang tidak termasuk dalam penelitian ini seperti metode guru mengajar, cara belajar siswa, media pembelajaran, fasilitas belajar, pendekatan belajar, dan lain-lain.

Pengelolaan kelas merupakan suatu keterampilan guru untuk mengelola kelas seperti pengaturan kondisi fisik kelas hingga penciptaan suasana belajar yang kondusif dengan mendayagunakan seluruh potensi siswa yang berada di lingkungan sekolah demi mencapai tujuan pembelajaran. Menurut Sardiman (2012:169): "Kegiatan mengelola kelas menyangkut mengatur tata ruang kelas yang memadai untuk pengajaran dan menciptakan iklim belajar mengajar yang serasi”. Kegiatan pengaturan kelas baik yang berkaitan dengan tata ruang kelas yang mendukung proses belajar pembelajaran di kelas dan menciptakan suatu kondisi belajar pembelajaran yang kondusif sangat menentukan keberhasilan untuk mencapai tujuan pembelajaran. Wina Sanjaya (2008:44) mengemukakan: "Pengelolaan kelas adalah keterampilan guru menciptakan dan memelihara kondisi belajar yang optimal dan mengembalikannya manakala terjadi hal-hal yang dapat menganggu suasana pembelajaran". Suatu kondisi proses belajar pembelajaran yang kondusif diciptakan guru disertai keterampilan guru yang tanggap untuk mengembalikannya apabila jika terjadi persoalan-persoalan yang mengganggu suasana pembelajaran maka dapat menyebabkan tercapainya tujuan pembelajaran. Tercapainya tujuan pembelajaran inilah menjadi indikator yang dapat mempengaruhi peningkatan hasil belaja

\section{CONCLUSIONS}

Berdasarkan analisis data yang telah dilakukan melalui pembahasan, maka ditarik kesimpulan penelitian sebagai berikut: (a) Pengelolaan kelas XI IPS1 Siswa Kelompok Tinggi dan Kelompok Rendah SMA Negeri Se-Kota Singkawang sudah berjalan dengan baik. Kondisi ini dapat dilihat dari rata-rata persentase indikator yaitu $77,08 \%$. (b) Hasil belajar mata pelajaran ekonomi Siswa kelas XI IPS1 Kelompok Tinggi dan Kelompok Rendah SMA Negeri Se-
Kota Singkawang termasuk kategori tinggi dengan nilai ratarata 77,33. (c) Pengelolaan kelas merupakan faktor determinatif terhadap hasil belajar siswa kelas XI IPS1 Kelompok Tinggi dan Kelompok Rendah SMA Negeri SeKota Singkawang. Kondisi ini dapat dijelaskan dari nilai persamaan regresinya adalah $\mathrm{Y}=52,657+0,466 \mathrm{X}$. Artinya nilai konstanta adalah 52,657 yaitu jika pengelolaan kelas (X) bernilai 0 (nol), maka hasil belajar (Y) bernilai 52,657. Selanjutnya, nilai koefisien regresi variabel pengelolaaan kelas (X) yaitu 0,466 ini berarti bahwa setiap peningkatan pengelolaan kelas sebesar satu, maka hasil belajar akan meningkat sebesar 0.466. Tingkat keeratan hubungan pengelolaan kelas dengan hasil belajar ditunjukkan dengan besarnya koefisien korelasi (R) sebesar 0,501, termasuk kategori sedang.

Penentuan pengaruh semua aspek variabel pengelolaan kelas terhadap nilai variabel hasil belajar ditunjukkan oleh besarnya koefisen determinasi $\left(\mathrm{R}^{2}\right)$ sebesar 0,251 artinya persentase sumbangan pengaruh pengelolaan kelas terhadap hasil belajar sebesar $25,1 \%$ sedangkan sisanya sebesar $74,9 \%$ dipengaruhi oleh variabel lain yang tidak termasuk dalam penelitian ini seperti metode guru mengajar, cara belajar siswa, media pembelajaran, fasilitas belajar, pendekatan belajar, dan lain-lain.

Beberapa saran yang dapat dikemukakan sebagai berikut: a) Guru hendaknya selalu memperhatikan dan meningkatkan pengelolaan kelas guna memperoleh hasil belajar yang lebih tingggi. Upaya tersebut dapat dilakukan dengan memperhatikan aspek-aspek dan indikator-indikator pengelolaan kelas yang mempengaruhi hasil belajar. (b) Untuk memudahkan tercapainya tujuan pembelajaran dalam rangka lebih meningkatkan hasil belajar hendaknya guru selalu menciptakan dan memelihara kondisi belajar yang optimal dan mengembalikannya ke kondisi yang optimal jika terjadi gangguan, baik dengan cara mendisiplinkan ataupun melakukan kegiatan remedial terhadap siswa. (c) Agar setiap siswa di kelas dapat bekerja dengan tertib untuk mencapai tujuan pembelajaran secara efektif dan efisien maka hendaknya guru melakukan pengelolaan siswa dan pengelolaan lingkungan kelas. Pengelolaan siswa pada dasarnya meliputi: keterampilan yang berhubungan dengan penciptaan dan pemeliharaan kondisi belajar yang optimal (bersifat preventif) seperti sikap tanggap, membagi perhatian, dan pemusatan perhatian kelompok; dan keterampilan yang berhubungan dengan pengembangan kondisi belajar yang optimal (bersifat refresif) seperti memodifikasi tingkah laku, pengelolaan kelompok, dan diagnosis penyebab gangguan. Sedangkan berkanaan dengan pengelolaan lingkungan hendaknya diciptakan lingkungan kelas yang kondusif, nyaman, menyenangkan, bersih dan rapi karena berperan penting dalam menunjang efektivitas pembelajaran.

\section{REFERENCES}

[1] Sardiman, Interaksi dan Motivasi Belajar Mengajar. Jakarta: PT Raja Grafindo Persada, 2014. 
J U R N A L Jurnal PIPSI: Jurnal Pendidikan Ilmu Pengetahuan Sosial Indonesia

Volume 1 Nomor 1 Bulan Maret, 2016 Halaman 6-10

p.ISSN: 2477-6254 e-ISSN: 2477-8427

[2] Sudirman N. dkk., Ilmu Keguruan, Cetakan V. Bandung: Remaja Rosdakarya, 1991.

[3] Mudasir, Manajemen Kelas. Yogyakarta: Zanafa Publishing, 2011

[4] M. Pidarta, Pengelolaan Kelas. Surabaya: Usaha Nasional.

[5] H. Nawawi, Organisasi Sekolah dan Pengelolaan Kelas, Cetakan III Jakarta: Haji Masagun, 1989.

[6] J. Santrock, Psikologi Guruan, Edisi Kedua, (Penterjemah: Tri Wibowo). Jakarta: Kencana, 2011.

[7] H. Hamid, Kemampuan Mengajar: Landasan Konsep dan Implementasi. Bandung: Alfabeta, 2012
[8] S.B.Djamarah dan A. Zain, Strategi Belajar Mengajar. Jakarta: Rineka Cipta, 2013.

[9] M. Syah, Psikologi Belajar. Jakarta: Rajawali, 2012.

[10] Abdurrahman, Pengelolaan Kelas. Surabaya: Usaha Nasional, 2011.

[11] W. Sanjaya, Strategi Pembelajaran Berorientasi Standar Proses Keguruan. Jakarta: Kencana Prenada Media, 2011

[12] J.J. Hasibuan dan Moedjiono, Proses Belajar Mengajar. Bandung: PT. Remaja Rosdakarya, 2010.

[13] Slameto, Belajar Mengajar. Jakarta: Erlangga, 2013. 